\title{
A new species of Gymnogeophagus Miranda Ribeiro from Uruguay (Teleostei: Cichliformes)
}

\author{
Marcelo Loureiro ${ }^{1,2}$, Matías Zarucki ${ }^{1}$, Luiz R. Malabarba ${ }^{3}$ and Iván González-Bergonzoni ${ }^{1}$
}

We describe a new species of a substrate-brooding Gymnogeophagus, based on coloration characters. The new species can be distinguished from the remaining substrate-brooding species in the genus by the unique pigmentation of the dorsal fin which consists of light blue, diagonal stripes over a red background in the spiny section and a combination of round, elliptic, and elongated bright blue spots over a red background in the soft section. It can be further distinguished from all other species of Gymnogeophagus by the following combination of characters: a discontinuous bright blue band above the upper lateral line in the humeral area, light blue roundish spots over a red to orange background on the anal fin, and conspicuous bright blue horizontal bands on body. The new species inhabits a wide range of freshwater habitats in the lower rio Uruguay basin, Rio de la Plata coastal drainages and Atlantic Ocean coastal drainages in Uruguay.

Describimos una nueva especie de Gymnogeophagus con incubación de sustrato, en base a caracteres cromáticos. La nueva especie puede ser diferenciada de las restantes especies del género por la exclusiva pigmentación de la aleta dorsal, la que consiste de bandas oblicuas de color celeste sobre fondo rojo en la porción espinosa y una combinación de manchas redondas, elípticas, o alargadas azul brillantes sobre fondo rojo en la porción blanda. Además puede ser distinguida de las otras especies de Gymnogeophagus por la siguiente combinación de caracteres: banda horizontal azul iridiscente situada por encima de la línea lateral superior discontinua en la región humeral, manchas azules brillantes redondeadas sobre fondo rojo anaranjado en la aleta anal, bandas horizontales azul brillante en el cuerpo conspicuas. La nueva especie habita una amplia gama de hábitats de agua dulce en el sector inferior de la cuenca del río Uruguay, los drenajes costeros del Río de la Plata y drenajes costeros del Océano Atlántico en Uruguay.

Keywords: Cichlidae, Gymnogeophagus meridionalis, Gymnogeophagus rhabdotus, Substrate brooding, Systematics.

\section{Introduction}

Neotropical cichlids are among the most diverse fish taxa in the Neotropics (Kullander, 2003) and represent an ecologically diversified clade (López-Fernández et al., 2005a, 2005b, 2010). New phylogenies of teleosts, which changed the position of cichlids within the acanthomorph tree (i.e. Near et al., 2012; Betancur-R. et al., 2013), have increased interest in their evolutionary innovations and homologies. Moreover, due to their high evolutionary and ecological diversification rates (López-Fernández et al., 2013; Astudillo-Clavijo et al., 2015; Seehausen, 2015) cichlids are useful models to study ecomorphological diversification mechanisms (Winemiller et al., 1995; Burress, 2015). Among Neotropical cichlids the Geophagini is the most diversified clade, not only in species number but also in morphology, ecology, and behavior. However, as in many other freshwater fish clades, knowledge of species diversity remains incomplete (Kullander, 2003), and phylogenetic and evolutionary hypotheses remain open. Neotropical cichlids form a monophyletic clade of which one of the most southerly distributed taxa is the geophagine genus Gymnogeophagus Miranda Ribeiro, with most species endemic to the La Plata basin, laguna dos Patos system, and rio Tramandaí drainage (Reis \& Malabarba, 1988; Malabarba et al., 2013, 2015). The only exception is a record of G. balzanii (Perugia, 1891) (CAS 48828) from the rio Guapore in the Amazon basin, that is connected to the headwaters of the rio Jauru of the rio Paraguay drainage (Lowe-McConnell, 1975: 47).

Gymnogeophagus species are distinguished from other cichlids by the presence of a forward-directed spine on top of the first dorsal-fin pterygiophore and by the absence of bony supraneurals (Gosse, 1976; Reis \& Malabarba, 1988; Wimberger et al., 1998). The monophyly of the genus has been largely corroborated by morphological and molecular

\footnotetext{
${ }^{1}$ Universidad de la República. Facultad de Ciencias, Departamento de Ecología y Evolución. Iguá 4225. CP 11400. Montevideo, Uruguay. (ML) mapy@fcien.edu.uy (corresponding author), (MZ) mzarucki@gmail.com, (IGB) ivan2002uy@hotmail.com.ar

${ }^{2}$ Departamento de Ictiología, Museo Nacional de Historia Natural, Montevideo.

${ }^{3}$ Departamento de Zoologia and Programa de Pós-Graduação em Biologia Animal, Universidade Federal do Rio Grande do Sul, Av. Bento Gonçalves, 9500, 91501-970 Porto Alegre, RS, Brazil. malabarb@ufrgs.br
} 
data (Reis \& Malabarba, 1988; Wimberger et al., 1998; Pereyra \& García, 2008; López-Fernández et al., 2010; Malabarba et al., 2010). However, species-level taxonomy and phylogenetic relationships, distribution patterns, and the evolutionary history of differences in reproductive behavior are still unclear. Gymnogeophagus species show contrasting reproductive strategies, with species being either mouth brooding or substrate brooding, the latter possibly forming a paraphyletic group (Wimberger et al., 1998). The substrate brooding species group is known informally as the "G. rhabdotus species group" and contains four described species: G. rhabdotus (Hensel, 1870), G. meridionalis Reis \& Malabarba, 1988, G. setequedas Reis, Malabarba \& Pavanelli, 1992, and G. che Casciotta, Gómez \& Toresanni, 2000. The mitochondrial haplotypes of several populations of $G$. rhabdotus and $G$. meridionalis from rio Uruguay and laguna dos Patos drainages, however, do not cluster as two separate species (Wimberger et al., 1998), suggesting the existence of cryptic species in that region and/or past introgression through hybridization.

In this article we describe a new species of substratebrooding Gymnogeophagus from the middle and lower rio Uruguay basin and coastal drainages of the Río de la Plata estuary and Atlantic Ocean in Uruguay and provide a diagnosis separating it from other substrate-brooding species. This species has been previously identified as $G$. rhabdotus (Stawikowski, 1983), provisionally identified as "G. rhabdotus" (Yafe et al., 2002) or misidentified as $G$. meridionalis (Reis et al., 1992: 268, fig. 4).

\section{Material and Methods}

We examined material of the new species and comparative material from other Gymnogeophagus species belonging to the fish collections of the California Academy of Sciences, San Francisco (CAS), Departamento de Zoologia, Universidade Federal do Rio Grande do Sul (UFRGS), Facultad de Ciencias de la Universidad de la República, Montevideo (ZVC-P), Museo Nacional de Historia Natural, Montevideo (MNHN), and Museu de Ciências e Tecnologia, Pontifícia Universidade Católica do Rio Grande do Sul (MCP). Additional comparisons were done using published data from Reis \& Malabarba (1988), Reis et al. (1992), and Casciotta et al. (2000); coloration comparisons with $G$. setequedas and $G$. che employed color photographs provided generously by J. Casciotta and Ariel Puentes, and those available on the website Paraguay Biodiversidad (http://www.pybio.org/). Counts and measurements were taken according to Reis \& Malabarba (1988) and González-Bergonzoni et al. (2009); E1 scale count refers to scales in the row immediately above that containing the lower lateral line. Cleared and stained (c\&s) specimens were prepared according to Dingerkus \& Ulher (1977) or Taylor \& Van Dyke (1985). Differences in meristic and morphometric measures were tested using Mann-Whitney U Tests, at $\alpha=0.05$ level using PAST 3.06 software (Hammer et al., 2001).

\section{Gymnogeophagus terrapurpura, new species}

urn:1sid:zoobank.org:act:4005F96C-115E-4A63-B46D7A221497CA54

\section{(Figs. 1-2A)}

Gymnogeophagus rhabdotus, non Hensel, 1870. Stawikowski, 1983 (photo).

Gymnogeophagus meridionalis, non Reis \& Malabarba, 1988. Reis et al., 1992: 268 (fig. 4, same specimen figured by Stawikowski, 1983 as G. rhabdotus).

Gymnogeophagus rhabdotus, non Reis \& Malabarba, 1988. Yafe et al., 2002 (feeding ecology).

Gymnogeophagus cf. meridionalis, non Reis \& Malabarba, 1988. Pereyra \& García, 2008 (mitochondrial phylogeny).

Gymnogeophagus sp. Serra et al., 2014:123 (photo, distribution); 182 (diagnosed in key).

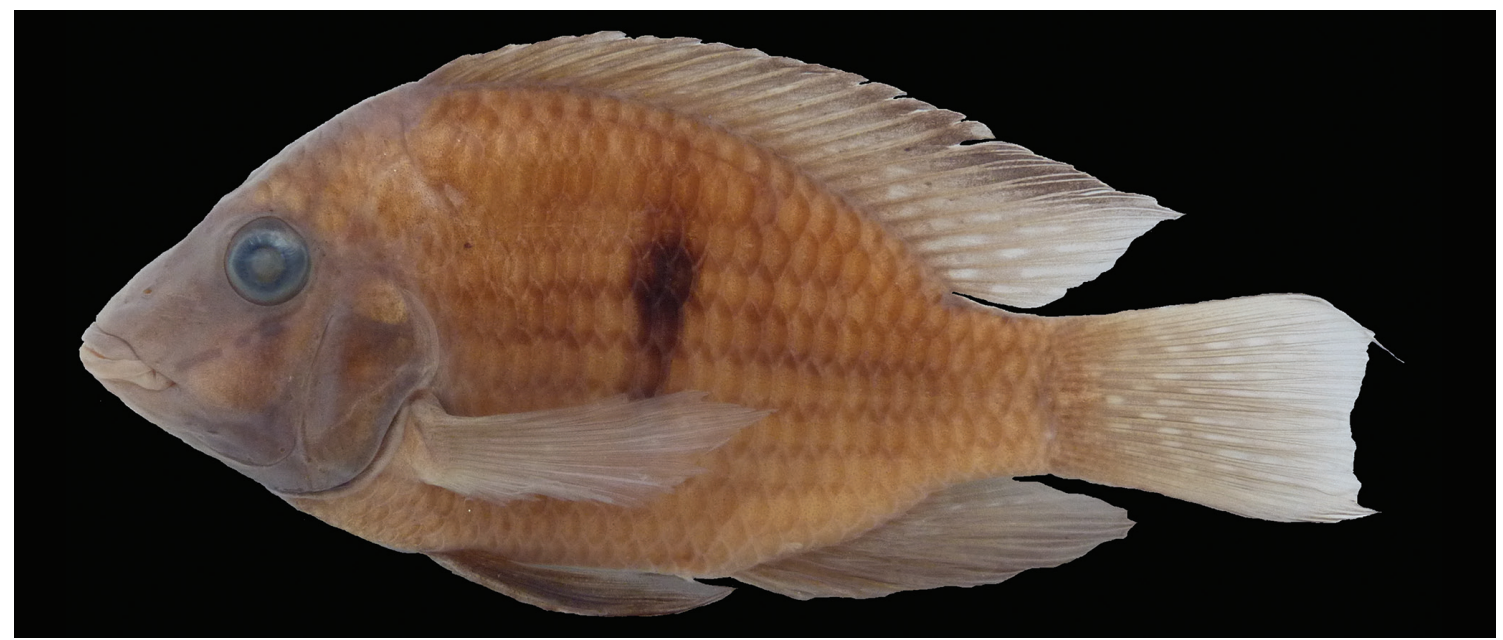

Fig. 1. Gymnogeophagus terrapurpura, new species, ZVC-P 12490, $60.0 \mathrm{~mm}$ SL, holotype, cañada de La Lana, rio Santa Lucía basin, Canelones Department, Uruguay. 


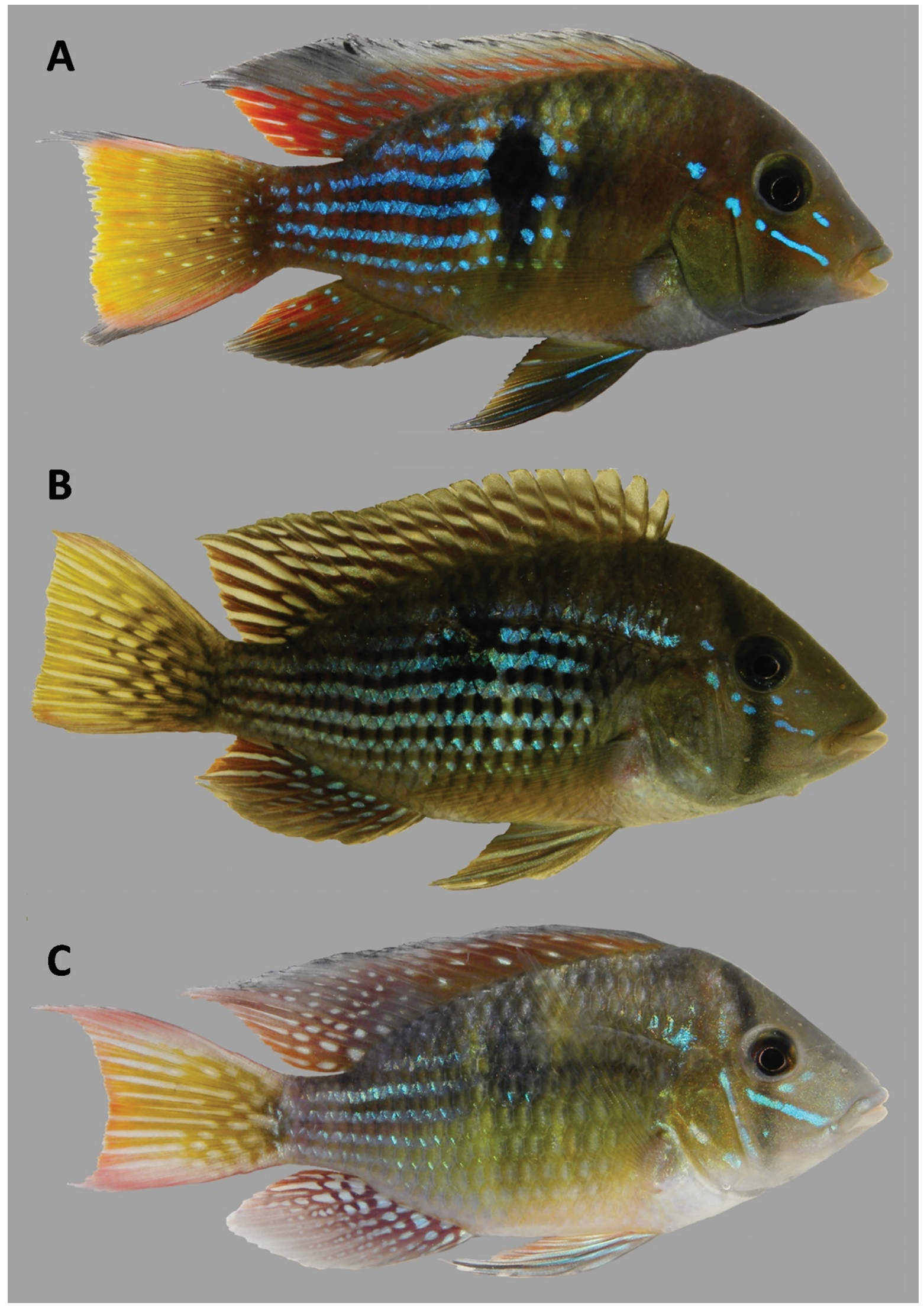

Fig. 2. Non-type live specimens of (A) Gymnogeophagus terrapurpura from rio Santa Lucía basin, Canelones Department, Uruguay, (B) G. rhabdotus and (C) G. meridionalis. (B) and (C) both from rio Negro basin, Tacuarembó Department, Uruguay. 
Holotype. ZVC-P 12490, 60.0 mm SL, Uruguay, Canelones Department, cañada de la Lana, close to Juanicó Town, rio Santa Lucía basin (Río de la Plata tributary), 34³5'55"S, $56^{\circ} 14^{\prime} 19^{\prime \prime}$ W, Sep 2009, F. Quintans.

Paratypes. Uruguay. Canelones Department. ZVC-P 9375, 1, 67.2 mm SL, same data as holotype; ZVC-P 8777, 1, $50.7 \mathrm{~mm}$ SL, arroyo Vejigas, Ruta 12, rio Santa Lucía basin, Río de la Plata tributary, $34^{\circ} 17^{\prime} 24^{\prime \prime S}, 55^{\circ} 53^{\prime} 11^{\prime \prime} \mathrm{W}$, Jun 2010, I. Gonzalez \& C. Rojas. Florida Department. ZVC-P 7448, 4, 37.5-71.7 mm SL (1 c\&s), cañada Las Piedras, rio Santa Lucía basin (Río de la Plata tributary), $34^{\circ} 16^{\prime} 20^{\prime \prime} \mathrm{S}, 56^{\circ} 20^{\prime} 06^{\prime} \mathrm{W}$, Oct 2007, R. Arocena, G. Chalar \& F. Quintans; ZVC-P 2339, 19, 34.9-72.3 (2, 62.6-66.3) mm SL, arroyo Casupá, rio Santa Lucía basin, Río de la

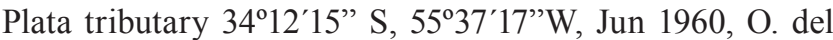
Puerto. San José Department. ZVC-P 81, 7, 33.4-81.4 (1, 82.4) $\mathrm{mm}$ SL, Sierra de Mahoma, arroyo Mahoma chico de la Sierra, rio Santa Lucía basin, Río de la Plata tributary, 3403'36"S, 56 56'32"W, Jun 1953, M. Siri; ZVC-P 985, 27, 29.2-86.6 (1, 88.3) mm SL, Paso del arroyo Mauricio, Río de la Plata tributary, 34²'18"S, 56 41'49” W, Dec 1959, J. Soriano. Montevideo Department. ZCV-P 3915, 9, 33.6-46.0 (1, 41.4) mm SL, Parque Rodó lake, Río de la Plata tributary, $34^{\circ} 54^{\prime} 45^{\prime \prime} \mathrm{S}, 56^{\circ} 10^{\prime} 01^{\prime \prime} \mathrm{W}$, Oct 1999, F. Scasso, F. Quintans, A. Yafe, \& M. Loureiro; ZVC-P 5746, 2, 62.0-94.0 (1, 92.2) mm SL; MNHN 3674, 4, 67.4-89.6, arroyo Las Piedras, rio Santa Lucía basin, Río de la Plata

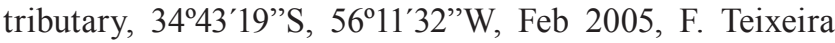
de Mello, L. Rubio \& N. Vidal. Lavalleja Department. ZVC-P 3839, 1, 62.5 mm SL, rio Santa Lucía, Arequita,

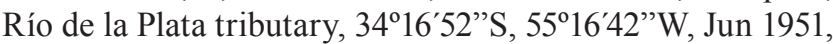
unknown collector; ZVC-P 5813, 2, 72.5-81.8 $(1,81.8) \mathrm{mm}$ SL, arroyo Mataojo, Ruta 81, Río de la Plata tributary, $34^{\circ} 30^{\prime} 13^{\prime \prime} S, 5^{\circ} 24^{\prime} 58^{\prime \prime}$ W, Nov 2004, N. Rajcok, H. Ferreira, I. Terzaghi, A. Viera, A. Sacchi \& M. Loureiro; Colonia Department. ZVC-P 197, 1, 70.9 mm SL, rio Uruguay,

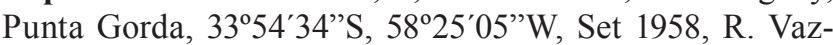
Ferreira, B. Sierra \& J. Soriano. Soriano Department. ZVC-P 7021, 2, 54.8-56.7 mm SL(1, $56.7 \mathrm{~mm} \mathrm{SL})$, rio San Salvador, rio Uruguay basin, $33^{\circ} 50^{\prime} 11^{\prime \prime} \mathrm{S}, 57^{\circ} 44^{\prime} 16^{\prime \prime} \mathrm{W}$, Nov 2005, F. Teixeira, A. D'Anatro, I. González, S. Oviedo \& M. Loureiro. Paysandú Department. ZVC-P 7028, 1, $51.1 \mathrm{~mm} \mathrm{SL}$, rio Queguay chico, Ruta 4, rio Uruguay

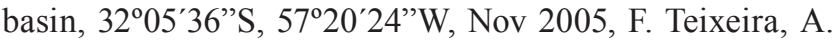
D'Anatro, I. González, S. Oviedo \& M. Loureiro; UFRGS 7934, 8, 29.9-74.0 mm SL, MCP 48718, 2, 52.4-52.6 mm $\mathrm{SL}$, cañada in ruta $4,10 \mathrm{Km}$ from ruta 26 , rio Queguay chico basin, rio Uruguay basin, 32 $01^{\prime} 57^{\prime \prime} \mathrm{S}, 57^{\circ} 19^{\prime} 30^{\prime \prime} \mathrm{W}$, Set 2005,V. Bertaco , F. Cantera, J. Ferrer \& L. Malabarba. Salto Department. ZVC-P 7018, 15, 50.9-69.4 mm SL(1, $52.2 \mathrm{~mm} \mathrm{SL} ; 1 \mathrm{c} \& \mathrm{~s})$, rio Arapey chico, ruta 4, rio Uruguay

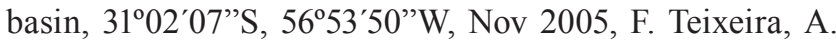
D'Anatro, I. González, S. Oviedo \& M. Loureiro; ZVC-P 7024, 11, 40.5-67.1 (3, 44.6-67.1) mm SL, rio Dayman, Ruta 4, rio Uruguay basin, $31^{\circ} 47^{\prime} 15^{\prime}$ 'S, $57^{\circ} 02^{\prime} 12^{\prime} \mathrm{W}$, Nov
2005, F. Teixeira, A. D'Anatro, I. González, S. Oviedo \& M. Loureiro. Tacuarembó Department. ZVC-P $3700,3,29.1-57.4(1,57.4) \mathrm{mm} \mathrm{SL}$, arroyo Laureles, rio Tacuarembó basin, rio Negro basin, rio Uruguay basin, $31^{\circ} 15^{\prime} 17^{\prime \prime} \mathrm{S}, 56^{\circ} 03^{\prime} 14^{\prime \prime} \mathrm{W}, \mathrm{Feb}$ 1954, Excursión Laboratorio de Zoología; ZVC-P 3714, 5, 34.5-68.3 mm SL (1, 63.2mm SL), arroyo Laureles, rio Tacuarembó basin, rio Negro

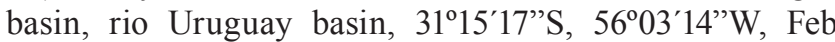
1954, Excursión Laboratorio de Zoología; ZVC-P 3722, 2 , 29.8-62.2 (1, 64.5) mm SL, arroyo Jabonería, Valle Edén, rio Tacuarembó basin, rio Negro basin, rio Uruguay basin, 31049'54"S, 56 11'45"W, Apr 1968, F. Achaval. Durazno Department. ZVC-P 4057, 3, 40.4-71.0 mm SL(2, 47.5-71.0 $\mathrm{mm}$ SL), arroyo Las Higueras, arroyo Carpinteria basin, rio Negro basin, rio Uruguay basin, $32^{\circ} 56^{\prime} 44^{\prime \prime} \mathrm{S}, 56^{\circ} 02^{\prime} 20^{\prime \prime} \mathrm{W}$, Oct 1959, E. Messner. Rocha Department. ZVC-P 280, 7, 55.8-86.9 $(1,89.8) \mathrm{mm}$ SL, arroyo Valizas, Ruta 10, laguna Castillos basin, Atlantic Ocean tributary, 34 $21^{\prime} 30^{\prime \prime}$, 5350'41"W, Mar 1959, R. Vaz-Ferreira, J. Soriano \& B. Soriano; ZVC-P 6049, 29, 18.6-71.2 (2, 41.4-72.8) mm SL, laguna de Brioso, Aguas Dulces, Atlantic Ocean

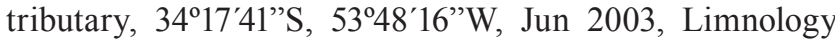
Section, Facultad de Ciencias; ZVC-P 6086, 1, $64.1 \mathrm{~mm}$ SL, arroyo Sarandí, Barra Grande, laguna Castillos basin, Atlantic Ocean tributary $34^{\circ} 14^{\prime} 19^{\prime \prime} \mathrm{S}, 53^{\circ} 58^{\prime} 46^{\prime \prime} \mathrm{W}$, Mar 2001, F. Scasso, N. Marchand \& A. D'Anatro; ZVC-P 7060, 2, 54.8-64.5 $(1,64.5) \mathrm{mm}$ SL (1 c\&s), cañada Sierras de Rocha, laguna de Rocha basin, Atlantic Ocean tributary, $34^{\circ} 21^{\prime} 56^{\prime}$ 'S, 54²4'34”W, Feb 2001, F. Scasso, M. Loureiro, F. Quintans \& J. Sawchik.

Diagnosis. The number of E1 scales, (23-25 vs. 26-30), and the substrate-brooding behavior distinguishes the new species from all other Gymnogeophagus species except for G. rhabdotus, G. meridionalis, G. setequedas, and G. che. It can be differentiated from those four species by the unique pigmentation of the dorsal fin, which consists of diagonal bright blue stripes (light brown in preserved specimens) over a red background (brown in preserved specimens) in the spiny section, and a combination of round, elliptical, and elongated bright blue spots (light brown in preserved specimens) in the soft section, vs. whitish light blue round spots (white to light brown in preserved specimens) over a red background (brown in preserved specimens) in the whole fin in G. meridionalis, or diagonal whitish light blue stripes (white to light brown in preserved specimens) over a red background in the whole spiny section of the fin and the distal 3/4 of the soft section in G. rhabdotus, G. setequedas, and G. che (Fig. 3). Gymnogeophagus terrapurpura can be further distinguished from G. rhabdotus by the termination of the bright blue band that runs above the upper lateral line before reaching a bright blue spot placed above the first perforated scale vs. band continuous with that spot. It can be further distinguished from $G$. meridionalis, $G$. setequedas, and $G$. che by the anal fin pigmentation pattern which consists of light blue rounded spots (light brown 
in preserved specimens) over a red to orange background (brown in preserved specimens) $v s$. white irregularly shaped spots over a dark red back ground in G. meridionalis (Fig. 4) or diagonal light stripes in G. setequedas and G. che (Reis et al., 1992; Casciotta et al., 2000). It is also distinguished from $G$. meridionalis by the absence of small clear spots between anal fin rays that reach the distal edge of the fin $v s$. presence of these spots (Fig. 2).
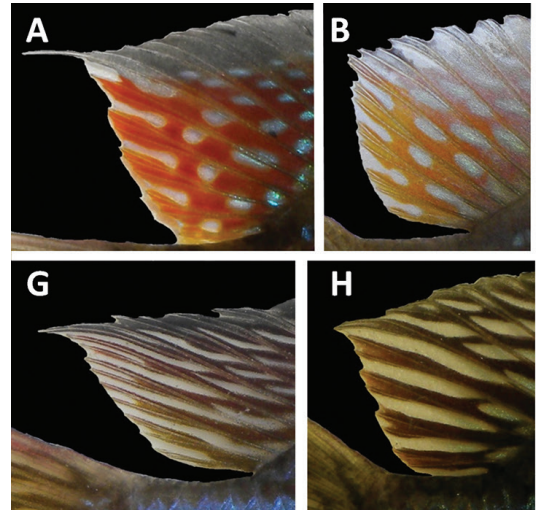
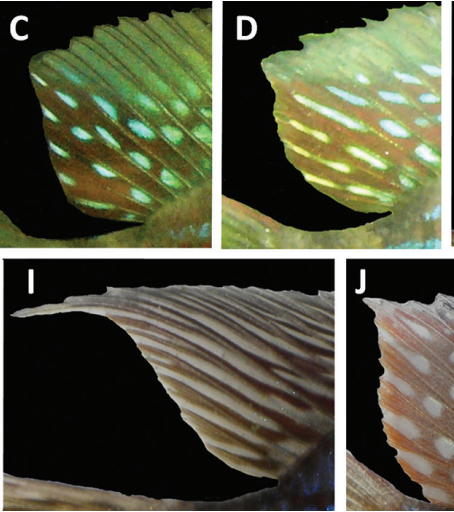
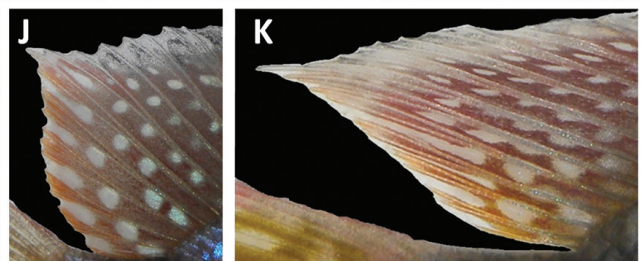

Fig. 3. Soft dorsal fin pigmentation patterns: (A-F) Gymnogeophagus terrapurpura, (G-I) G. rhabdotus, (J-K) G. meridionalis.
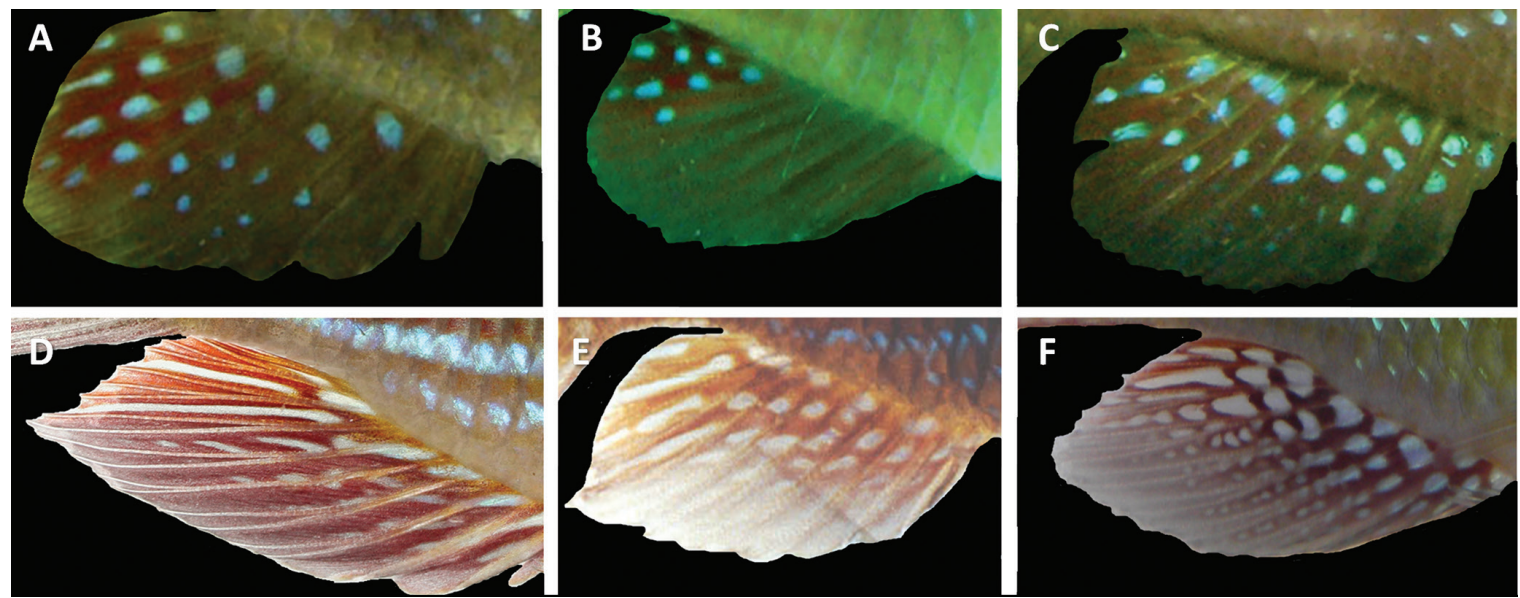

Fig. 4.Anal fin pigmentation patterns: (A-C) Gymnogeophagus terrapurpura, (D-E) G. rhabdotus, (F) G. meridionalis.

Description. Meristic and morphometric data summarized in Table 1 and Table 2. Body compressed, moderately elongated. Predorsal contour slightly convex; body contour at dorsal-fin base convex, decreasing in depth to caudal peduncle. Caudal peduncle rectangular, deeper than long, dorsal and ventral profiles slightly concave. Body contour slightly convex between lower lip and last anal-fin ray, with straight segment between pelvic and anal fins.

Snout pointed, nearly straight dorsally and ventrally in lateral aspect; short and anteriorly rounded in dorsal aspect. Eye small, close to dorsal profile of head; eye near middle of head length. Interorbital area convex, more strongly so in larger specimens; interorbital width larger than eye diameter. Posterior tip of maxilla not reaching vertical through anterior margin of eye. Mouth terminal, jaws isognathous.

Body scales ctenoid except for small cycloid scales mixed with ctenoid scales in preventral area. Small ctenoid scales on opercle; scales on preopercle small and cycloid. Caudal fin with small scales in single row between rays, from 5 to 7 series at level of lower lateral line and covering proximal third of fin on dorsal and ventral borders of fin. Other unpaired fins without scales.

Dorsal-fin origin anterior to vertical line through posterior bony margin of opercle, posterior end of depressed fin reaching caudal-fin base. Pectoral-fin edge at anal-fin origin. Anal-fin edge at caudal-fin base. Caudal fin truncate or slightly concave.

Vertebrae, 26 (13 abdominal, 13 caudal). Pectoral radials, 4. Gill rakers on first branchial arch, 12-13. Numerous canine-like teeth on upper pharyngeal jaws (Fig. 5A), 1011 slender on second pharyngobranchial, up to 40 more robust and larger on third pharyngobranchial, numerous and smaller on fourth. Second pharyngobranchial slender; third pharyngobranchial (the largest) fan-shaped; fourth pharyngobranchial triangular. Numerous teeth on lower pharyngeal jaws (fifth ceratobranchials); slender, conical, and pointed on edge, robust and rounded at center (Fig. 5B). Fifth ceratobranchial triangular, with robust lateral and anterior processes. 


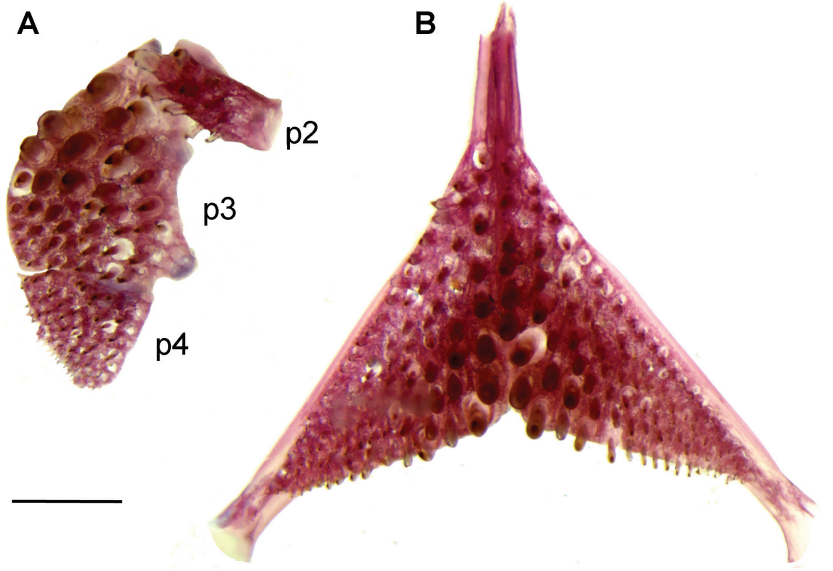

Fig. 5. Pharyngeal jaws of a $54.8 \mathrm{~mm}$ SL Gymnogeophagus terrapurpura paratype (ZVC-P 7060); (A) Ventral view of left upper pharyngeal jaws; (B) Dorsal view of lower pharyngeal jaws; p2-4 = pharyngobranchials 2-4. Scale bar $=1 \mathrm{~mm}$.
Table 1. Frequency distribution of meristic characters of paratypes and holotype* of Gymnogeophagus terrapurpura, total $\mathrm{n}=40$; (number of specimens).

\begin{tabular}{|c|c|c|c|c|c|c|}
\hline $\begin{array}{l}\text { Dorsal-fin } \\
\text { spines }\end{array}$ & $14(21)$ & $15 *(13)$ & & & & \\
\hline $\begin{array}{l}\text { Dorsal-fin } \\
\text { soft rays }\end{array}$ & $8(23)$ & $9 *(10)$ & & & & \\
\hline Anal fin & III+7 (17) & III+8 (14) & $\mathrm{III}+9 *(2)$ & & & \\
\hline Pectoral fin & $13(40)$ & & & & & \\
\hline Pelvic fin & $\mathrm{I}+5(40)$ & & & & & \\
\hline $\begin{array}{l}\text { Upper lateral } \\
\text { line scales }\end{array}$ & $14 *(6)$ & $15(8)$ & $16(13)$ & $17(5)$ & & \\
\hline $\begin{array}{l}\text { Lower lateral } \\
\text { line scales }\end{array}$ & $5(2)$ & $6(6)$ & $7(8)$ & $8 *(9)$ & $9(4)$ & $10(1)$ \\
\hline E1 scales & $23(9)$ & 24 (19) & $25 *(4)$ & & & \\
\hline
\end{tabular}

Table 2. Morphometric data of Gymnogeophagus terrapurpura, G. meridionalis, and G. rhabdotus. Measurements expressed as percentages of standard length, except those marked with *, which are percentages of head length.

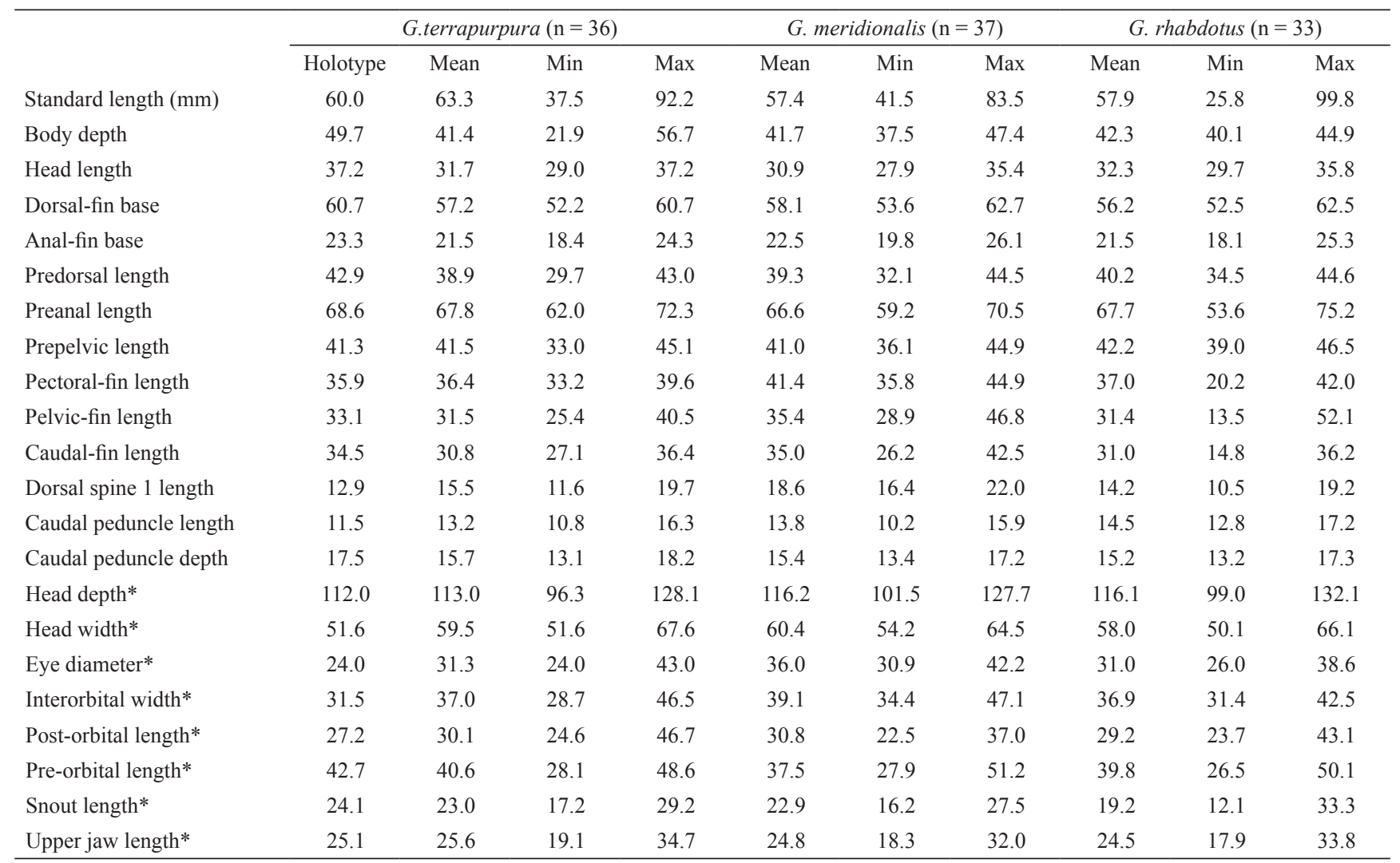

Color in life. Background color of dorsal region of body and head in adults light brown to olivaceous with up to seven diffuse and darker bars; first bar traversing eye from nape to ventral edge of preopercle. Black vertically elongated mid-lateral spot at third or fourth vertical band, surrounded by bright, yellow area in some specimens. Six to eight horizontal bright blue bands from behind pectoral-fin base to caudal-fin base; uppermost band interrupted in humeral region. Scales between bands red. Ventral portion of body and head light yellow to white; isthmus and branchiostegal region black in adult males and females during reproductive season. Numerous small bright blue, rounded or elongated dots usually present on cheeks, forming interrupted nearly straight line from 
upper portion of opercle-preopercle contact area behind eye to posterior tip of maxilla; usually one or two dots or elongated dots present anteroventral to eye. Dorsalfin background red with diagonal bright blue stripes in spiny portion; roundish, elliptic, and elongated spots in soft portion; dorsal fin border black in reproductive adults. Anal-fin background yellow to ochre in proximal and anterior portion, red distally; fin with small, bright blue, circular spots sometimes absent on distal half. Caudal-fin background red in adults, entirely covered with numerous circular to elongated hyaline spots, arranged in horizontal series between rays. Pectoral fin hyaline; pelvic fin olivaceous green to light brown, with light blue stripes between rays.

Color in alcohol. Background color brown. Red and yellow pigmentation of live specimens becomes brown or gray and light blue fin pigmentation turns hyaline to light brown. Dark spots turn darker and lateral parallel light blue bands turn brown, darker than background.

Sexual dimorphism. There is no evident sexual dimorphism except from slight differences in size. In the breeding season males are usually larger than females (10\%-50\% larger).

Geographic distribution. Gymnogeophagus terrapurpura is distributed from the rio Arapey (in the middle rio Uruguay basin) to all tributaries of the lower rio Uruguay basin and in the eastern coastal drainages of the Río de la Plata estuary and Atlantic Ocean in Uruguay (Fig. 6).

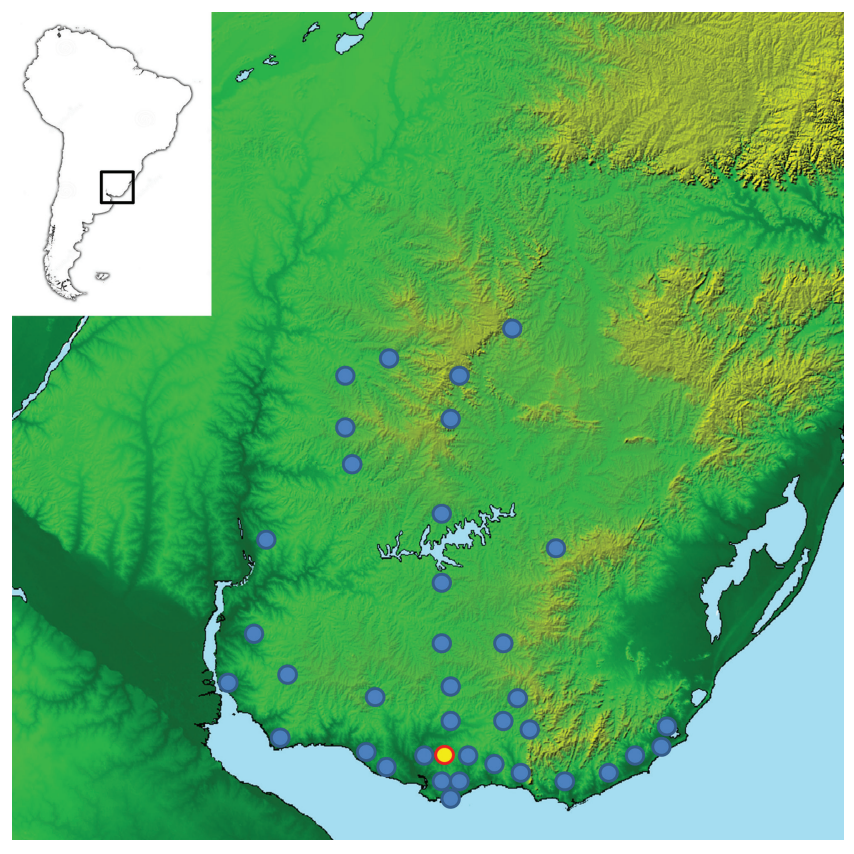

Fig. 6. Distribution of Gymnogeophagus terrapurpura. Yellow dot indicates type locality. Map modified from Shuttle Radar Topography Mission (SRTM), Courtesy NASA/JPL-Caltech.
Ecological notes. Gymnogeophagus terrapurpura has been found in a large variety of habitats including shallow lakes, floodplain lakes, rivers, and streams, mainly associated with cobble, sandy or muddy substrates. Gymnogeophagus terrapurpura is an omnivore, feeding on zooplankton, macroinvertebrates, and periphyton (to a lesser extent), reducing greatly its feeding activity during autumn and winter when water temperature decreases, as described in a low-impacted lowland stream in Florida Department by González-Bergonzoni et al. (2016, named therein as "Gymnogeophagus sp.") and in a eutrophic shallow lake of Montevideo by Yafe et al. (2002, named therein as $G$. rhabdotus). Gymnogeophagus terrapurpura has been observed to brood on the substrate and exhibits substantial parental care, including aggressive territorial behavior in both males and females during the reproductive season, from November to January.

Etymology. The specific epithet refers to the G. E. Hudson novel "La Tierra Purpúrea" (as it is known in the Spanish translation), in which the main character makes a trip through the same region where the new species occurs. A noun in apposition.

Conservation status. Gymnogeophagus terrapurpura is relatively frequent and abundant in the rio Negro, the middle and lower rio Uruguay basin, and in the oriental coastal drainages of Río de la Plata estuary and Atlantic Ocean in Uruguay. No specific threats were detected, and the species can be categorized as Least Concern (LC) according to IUCN criteria (International Union for Conservation of Nature (IUCN), 2011).

\section{Discussion}

The new species possesses the diagnostic characters of the genus (Reis \& Malabarba, 1998). Its body shape, E1 scale count, body coloration, and brooding behavior, easily place it within the substrate brooding species group. Hypothesizing affinities within the group is less straightforward. Apart from the unique elements of the coloration pattern of the dorsal fin, it shares different character states with different species. For example, it shares the pigmentation pattern of the spiny dorsal fin, consisting of diagonal light blue stripes over red background, with G. rhabdotus, G. setequedas and G. che. Although the original descriptions of the latter two species lack information on dorsal fin coloration, comparison of photos of living specimens from type localities showed that the color of their dorsal fin is indeed similar to that of $G$. terrapurpura and G. rhabdotus. Conversely, $G$. terrapurpurea shares with G. setequedas, G. che, and G. meridionalis a humeral area lacking a light blue band, while the intensity of the horizontal bright blue bands on the flanks of the new species resembles the coloration of $G$. rhabdotus. 
Pigmentation pattern of the anal fin of the new species consists of bright blue spots over red background, which is similar to some, but not all individuals of G. rhabdotus. In G. rhabdotus, this character can even vary among individuals from the same locality. Although the anal fin in most specimens typically has diagonal stripes, round spots can be observed. Furthermore, both G. terrapurpura and G. rhabdotus vary in the shape of the blue markings of the caudal fin. In most specimens of G. rhabdotus these marks take the form of stripes, however, some individuals from different regions present round to elongated spots. The opposite pattern occurs in G. terrapurpura, in which most individuals display round spots and few individuals possess horizontal stripes. According to the original description, the anal fin pattern of $G$. setequedas always consists of diagonal stripes and the caudal fin lacks both stripes or rounded spots (Reis et al., 1992), while the anal fin of G. che has diagonal stripes and the caudal fin has stripes (Casciotta et al., 2000).

The new species also differs statistically and significantly in meristics and morphometrics from G. meridionalis. It has, on average, a higher dorsal fin spine count; 14-15 (mode 14) vs. 12-14 (mode 13) (Mann-Whitney $\mathrm{U}$ test: $\mathrm{P}<0.001$ ); lower mean height of the first dorsal spine (expressed as percentage of body length) 15.7 (11.9-19.7) vs. 18.6 (16.422.0) (Mann-Whitney U test: $\mathrm{P}<0.001)$. Additional meristic differences with $G$. che involve the soft dorsal-fin rays with range 8-9 (mode 8) vs. 9-10 (mode 10) and 23-25 E1 scales (mode 24) vs. 24-26 (mode 26). Meristic differences with $G$. setequedas involve the soft dorsal-fin rays with range 8-9 (mode 8) vs. 9-11, and dorsal-fin spines 14-15 (mode 14) vs. 12-14.

Because all the species in this group are very similar, complete information on fin coloration is still lacking for some of them, and several cryptic species are thought to exist (Wimberger et al., 1998). A complete morphological revision accompanied by a molecular phylogeny is needed to build a robust hypothesis of relationships of Gymnogeophagus.

There are two additional names referred to the Gymnogeophagus rhabdotus species group, G. arcoiris and $G$. artiguensis, described as new species from Uruguay in a manuscript first distributed as a pdf file sometime after 2004 and before 2006. Both names, however, are unpublished and unavailable because they do not satisfy the criteria from Articles 8.1.3; 8.4; 8.5 and 78.2.4 of the International Code of Zoological Nomenclature. It is important to note that the reference to these names herein does not render them available (ICZN Article 11.5.2).

The new species has been found coexisting with $G$. meridionalis and G. rhabdotus throughout the rio Negro basin (Serra et al., 2014). Gymnogeophagus terrapurpura also coexists with G. meridionalis in the lower rio Uruguay drainage. It is interesting that the northern and eastern limits of the distribution of G. terrapurpura are congruent with the distribution of the characid Ectrepopterus uruguayensis (see Malabarba et al., 2012: fig. 7). The northern limit of G. terrapurpura is the rio Arapey, and the species disappears abruptly in the tributaries further to the north in the rio Uruguay basin. It is also found in all the eastern tributaries of the lower rio Uruguay basin and coastal drainages of the Río de la Plata Estuary, to the laguna Castillos basin (Atlantic Ocean drainage). This distribution range is presently disrupted by the salinity barrier of the Río de la Plata estuary and Atlantic Ocean. However, during the Pleistocene the sea level was much lower (Ayup-Zouain, 2006; Bracco Boksar et al., 2011) and these systems were probably connected through an extended coastal plain allowing dispersal of freshwater fish species. In this context, most of the laguna Castillos ichthyofauna belongs to the "Patos" Ecoregion (Loureiro \& García, 2006). However, G. terrapurpura, along with another "platense" Geophagine, Crenicichla scotti, share the same distribution in the basin, suggesting a complex historical biogeographic scenario and making the area potentially interesting for studying the evolution of areas of endemism.

Comparative material examined. Gymnogeophagus meridionalis: Uruguay: Artigas Department: ZVC-P 2347, 2, 45.1-53.7 mm SL (1 c\&s), Barra del arroyoYucutujá, Est. El Ombú, rio Cuareim basin, rio Uruguay basin; ZVC-P 2352, 1, 48.5mm SL, rio Cuareim, Región de Sepultura, Picada del Negro Muerto, rio Uruguay basin; ZVC-P 1266, 1, $55.3 \mathrm{~mm} \mathrm{SL}$, arroyo de la Invernada, rio Cuareim basin, rio Uruguay basin; ZVC-P 3735, 1, $59.1 \mathrm{~mm} \mathrm{SL}$, lagoons next to las Lavanderas lagoon (laguna de los Negros), rio Cuareim basin, rio Uruguay basin; ZVC-P 2431, 1, $63.2 \mathrm{~mm} \mathrm{SL}$, Arrocera Conti rio Uruguay, in front of Zapallo island; ZVC-P 7469, 1, $50.8 \mathrm{~mm}$ SL, rio Cuareim, Paso de la Cruz, rio Uruguay basin; ZVC-P 8342, 3, 55.5-60.1mm SL, arroyo Catalán grande, Ruta 30, rio Cuareim basin, rio Uruguay basin. Salto Department. ZVC-P 7017, 2, 53.2-60.7 mm SL, rio Arapey Chico, ruta 4, rio Uruguay basin. Paysandú Department: ZVC-P 8771, 1, 66.7 mm SL, rio Uruguay, Paysandú-Colón bridge; ZVC-P 2803, $55.1 \mathrm{~mm} \mathrm{SL}$, pond next to Paysandú-Colón bridge, rio Uruguay basin. Río Negro Department: ZVC-P 4722, 1, $56.1 \mathrm{~mm} \mathrm{SL}$, arroyo Farrapos, rio Uruguay basin. Cerro Largo Department: ZVC-P 2448, 3, 41.5-55.9mm SL; ZVC-P $2868,2,51.2-68.2 \mathrm{~mm}$ SL, laguna Mazangano, rio Negro basin, La Plata basin. Durazno Department: ZVC-P 3398, 1, 59.2mm SL; ZVC-P 7020, 2, 61.8-62.4 mm SL rio Negro Paraje 329, rio Negro basin; ZVC-P 2603, 2, 45.1-65.4 mm SL, arroyo Cordobés, Paso del Gordo, rio Negro basin. Tacuarembó Department: ZVC-P 4027, 2, 60,6-61,3 mm SL, laguna de las Lavanderas, Tacuarembó city, rio Tacuarembó basin, rio Negro basin. Colonia Department. ZVC-P 8770, 1, 61.8, rio Rosario, La Paz, Río de la Platatributary. Rocha Department.ZVC-P 8272, 3, 44.3-83-5 $\mathrm{mm}$ SL (1c\&s), laguna de los Moros (Amaya), laguna Castillos basin, Atlantic Ocean tributary. Argentina. ZVC-P 3712, 2, 49.6-62.8 mm SL, Entre Ríos Province, arroyo Chajarí, rio Uruguay basin. Gymnogeophagus rhabdotus: Uruguay. Rivera Department: ZVC-P 8775, 1, 56.8mm SL, arroyo Cuñapirú, rio Tacuarembó basin, rio Negro basin. Durazno Department: 
ZVC-P 1324, 1, 32.8 mm SL, Pozo en cañada afluente del arroyo Cordobés, rio Negro basin; ZVC-P 2830, 1, 23.4 mm SL, arroyo Cordobés, laguna próxima al Paso de la Cruz, rio Negro basin; ZVC-P 2530, 1, 57.1 mm SL, arroyo Cordobés, Paso de la Cruz, rio Negro basin; ZVC-P 8774, 1, 44.3mm SL, rio Negro Paraje 329, rio Negro basin. Cerro Largo Department: ZVC-P 8773, 2 , 55.93-59.79 mm SL, laguna Mazangano, Pozo Cañada lado Norte, río Negro basin; ZVC-P 6278, 2, 53.8-69.6 mm SL; ZVC-P 7034, 2, 25.8-61.9 mm SL, Cañada Tres Boliches, Ruta 8, rio Tacuarí basin, laguna Merín basin; ZVC-P 6301, 2, 55.7-61.2mm SL, rio Tacuarí, Ruta 8, laguna Merínbasin; ZVC-P 7039, 2, 47.4-57.5mm SL, arroyo de Las Cañas, Paso de las Cañas, rio Yaguarón basin, laguna Merín basin. Treinta y Tres Department: ZVC-P 6276, 3, 55.2-66.7mm SL, arroyo de las Averias, Paso del Aguila, rio Olimar basin, laguna Merín basin; ZVC-P 5654, 1, 49.7mm SL, arroyo de las Pavas, Ruta7 Km 234, Valentines, Estancia "Los Platanos", rio Olimar basin, laguna Merín basin; ZVC-P 7035, 1, 47.9 mm SL, rio Olimar grande, Paso de Rubio, laguna Merín basin. Lavalleja Department: ZVC-P 6282, 4, 29.7-66.4 mm SL, arroyo de los Chanchos (Villa Serrana dam), rio Cebollatí basin, laguna Merín basin; ZVC-P 1918, 2, 60.4-75.6mm SL (1 c\&s); ZVC-P 6274, 2, 54.4-69.4 mm SL, arroyo de los Chanchos, Villa Serrana, rio Cebollatí basin, laguna Merín basin; ZVC-P 1107, 2, 44.3-72.6 mm SL, arroyo Tapes de Godoy, rio Cebollatí basin, laguna Merín basin. Rocha Department: ZVC-P 5101, 1, $44.5 \mathrm{~mm}$ SL, Ruta 15, canal de arroceras, rio San Luis basin, laguna Merín basin. Maldonado Department: ZVC-P 6831, 1, $49.5 \mathrm{~mm}$ SL, arroyo Sauce, Ruta 109, laguna Merín basin. Gymnogeophagus sp: Uruguay. Artigas Department: Rio Cuareim basin, rio Uruguay basin. ZVC-P 7423, 3, 29.7-64.0 mm SL, arroyo Cuaró chico, Ruta 4; ZVC-P 7424, 1, 32.0 mm SL, arroyo Pelado, Ruta 4; ZVC-P 7428, 2, 53.9-70.8 mm SL (1 c\&s), rio Cuareim, Rincón de Pacheco; ZVC-P 7467 1, 67.6 mm SL (1 c\&s), arroyo Los Molles; ZVC-P 7473, 1, 54.8 mm SL, arroyo Catalán grande, Paso Urumbeba; ZVC-P 8301, 1, $52.1 \mathrm{~mm}$ SL, arroyo Canelera, arroyo Yucutujá basin; ZVC-P 8327, 1, 58.1 mm SL, arroyo Cuaró Chico.

\section{Acknowledgements}

We thank Sebastián Serra for the original pictures of Figure 2, Jorge Casciotta, and Ariel Puentes for the photographic material lent, and Edward Burress for the language corrections. This study was partially funded by CSIC (UdelaR), PDT 71/08. ML and IGB also received support from SNI, ANII (Agencia Nacional de Investigación e Innovación, Uruguay), and LRM from CNPq (Conselho Nacional de desenvolvimento Científico e Tecnológico, Brazil, Process \# 300705/2010-7).

\section{References}

Astudillo-Clavijo, V., J. H. Arbour \& H. López-Fernández. 2015. Selection towards different adaptive optima drove the early diversification of locomotor phenotypes in the radiation of Neotropical geophagine cichlids. BMC Evolutionary Biology, 15: 77.
Ayup-Zouain, R. 2006. Evolución paleogeográfica y dispersión de los sedimentos del Río de la Plata. Pp. 1-8. In: Menafra, R., L. Rodríguez-Gallego, F. Scarabino \& D. Conde (Eds.). Bases para la conservación y el manejo de la costa uruguaya. Montevideo, Vida Silvestre Uruguay.

Betancur-R., R., R. E. Broughton, E. O. Wiley, K. Carpenter, J. A. López, C. Li, N. I. Holcroft, D. Arcila, M. Sanciangco, J. C. Cureton II, F. Zhang, T. Buser, M. A. Campbell, J. A. Ballesteros, A. Roa-Varon, S. Willis, W. C. Borden, T. Rowley, P. C. Reneau, D. J. Hough, G. Lu, T. Grande, G. Arratia \& G. Ortí. 2013. The tree of life and a new classification of bony fishes. PLOS Currents Tree of Life, 2013 Apr. 18. Edition, doi: 10.1371/currents.tol.53ba26640df0ccaee75bb165c8c26288.

Bracco Boksar, R., F. García-Rodriguez, H. Inda, L. del Puerto, C. Castiñeira \& D. Panario. 2011. Niveles relativos del mar durante el Pleistoceno final-Holoceno en la costa de Uruguay. Pp. 6592. In: García-Rodríguez, F. (Ed.). El Holoceno en la zona costera de Uruguay. Montevideo, Universidad de la República - Comisión Sectorial de Investigación Científica (CSIC).

Burress, E. D. 2015. Cichlid fishes as models of ecological diversification: patterns, mechanisms, and consequences. Hydrobiologia, 748: 7-27.

Casciotta, J. R., S. E. Gómez \& N. I. Toresanni. 2000. Gymnogeophagus che, una nueva especie de la familia Cichlidae de la Cuenca del río Paraná (Perciformes, Labroidei). Revista del Museo Argentino de Ciencias Naturales, 2: 53-59.

Dingerkus, G. \& L. D. Uhler. 1977. Enzyme clearing of alcian Blue stained whole small vertebrates for demonstration of cartilage. Stain Technology, 52: 229-232.

González-Bergonzoni, I., E. Jeppesen, N. Vidal, F. Teixeira-de Mello, G. Goyenola, A. López-Rodriguez \& M. Meerhoff. 2016. Potential drivers of seasonal shifts in fish omnivory in a subtropical stream. Hydrobiologia, 768: 183-196.

González-Bergonzoni, I., M. Loureiro \& S. Oviedo. 2009. A new species of Gymnogeophagus from the río Negro and río Tacuarí basins, Uruguay (Teleostei: Perciformes). Neotropical Ichthyology, 7: 19-24.

Gosse, J. P. 1976. Révision du genre Geophagus (Pisces Cichlidae). Académie Royale des Sciences d'Outre-Mer, 19: 1-173 + 5 planches, 35 figs.

Hammer, Ø., D. A. T. Harper \& P. D. Ryan. 2001. PAST: Paleontological Statistics Software Package for Education and Data Analysis. Palaeontologia Electronica, 4: 1-9.

International Union for Conservation of Nature (IUCN) standards and additions subcommittee guidelines for using the IUCN. 2001. Red List Categories and Criteria Version 3.1. Prepared by the standards and additions subcommittee, Gland, Switzerland, IUCN. Available from: http://www.iucnredlist. org/technical-documents/categories-and-criteria/2001categories-criteria. (28 April 2015).

Kullander, S. O. 2003. Family Cichlidae (Cichlids). Pp. 605-654. In: Reis, R. E., S. O. Kullander \& C. J. Ferraris Jr, (Orgs.). Check list of the freshwater fishes of South and Central America. Porto Alegre, Edipucrs.

López-Fernández, H., J. H. Arbour, K. O. Winemiller \& R. L. Honeycutt. 2013. Testing for ancient adaptive radiations in Neotropical Cichlid fishes. Evolution, 67: 1321-1337.

López-Fernández, H., R. L. Honeycutt, M. L. J. Stiassny \& K. O. Winemiller. 2005a. Morphology, molecules, and character congruence in the phylogeny of South American geophagine cichlids (Perciformes, Labroidei). Zoologica Scripta, 34: 627-651. 
López-Fernández, H., R. L. Honeycutt \& K. O. Winemiller. 2005 b. Molecular phylogeny and evidence for an adaptive radiation of geophagine cichlids from South America (Perciformes: Labroidei). Molecular Phylogenetics and Evolution, 34: 227244.

López-Fernández, H., K. O. Winemiller \& R. L. Honeycutt. 2010. Multilocus phylogeny and rapid radiations in Neotropical cichlid fishes (Perciformes: Cichlidae: Cichlinae). Molecular Phylogenetics and Evolution, 55: 1070-1086.

Loureiro, M. \& G. García. 2006. Transgresiones y regresiones marinas en la costa Atlántica y lagunas costeras de Uruguay: efectos sobre los peces continentales. Pp. 545-555. In: Menafra, R., L. Rodríguez-Gallego, F. Scarabino \& D. Conde (Eds.). Bases para la conservación y el manejo de la costa uruguaya. Montevideo, Vida Silvestre Uruguay.

Lowe-McConnell, R. H. 1975. Fish communities in tropical freshwater: their distribution, ecology, and evolution. London, New York, Longman, 337p.

Malabarba, L. R., V. A. Bertaco, F. R. Carvalho \& T. O. Litz. 2012. Revalidation of the genus Ectrepopterus Fowler (Teleostei: Characiformes), with the redescription of its type species, E. uruguayensis. Zootaxa, 3204: 47-60.

Malabarba, L. R., P. Carvalho Neto, V. A. Bertaco, T. P. Carvalho, J. F. dos Santos \& L. G. S. Artioli. 2013. Guia de identificação dos peixes da bacia do rio Tramandaí. Porto Alegre, Ed. Via Sapiens, 140p.

Malabarba, M. C., L. R. Malabarba \& C. Del Papa. 2010. Gymnogeophagus eocenicus, n. sp. (Perciformes: Cichlidae), an eocene cichlid from the Lumbrera Formation in Argentina. Journal of Vertebrate Paleontology, 30: 341-350.

Malabarba, L. R., M. C. Malabarba \& R. E. Reis. 2015. Descriptions of five new species of the Neotropical cichlid genus Gymnogeophagus Miranda Ribeiro, 1918 (Teleostei: Cichliformes) from the rio Uruguay drainage. Neotropical Ichthyology, 13: 637-662.

Near, T. J., R. I. Eytan, A. Dornburg, K. L . Kuhn, J. A . Moore, M. P. Davis, P. C. Wainwright, M. Friedman \& W. L. Smith. 2012. Resolution of ray-finned fish phylogeny and timing of diversification. Proceedings of the National Academy of Sciences of the United States of America, 109: 13698-13703.

Pereyra, S. \& G. García. 2008. Patterns of genetic differentiation in the Gymnogeophagus gymnogenys species complex, a neotropical cichlid from South American basins. Environmental Biology of Fishes, 83:245-257.
Reis, R. E. \& L. R. Malabarba. 1988. Revision of the Neotropical Cichlid genus Gymnogeophagus Ribeiro, 1918, with descriptions of two new species (Pisces, Perciformes). Revista Brasileira de Zoologia, 4: 259-305.

Reis, R. E., L. R. Malabarba \& C. S. Pavanelli. 1992. Gymnogeophagus setequedas, a new cichlid species (Teleostei: Labroidei) from middle rio Paraná system, Brazil and Paraguay. Ichthyological Exploration of Freshwaters, 3: 265-272.

Seehausen, O. 2015. Process and pattern in cichlid radiations - inferences for understanding unusually high rates of evolutionary diversification. New Phytologist, 207: 304-312.

Serra, S., J. Bessonart, F. Teixeira de Mello, A. Duarte, L. Malabarba \& M. Loureiro. 2014. Peces del Río Negro. Montevideo, MGAP-DINARA, 207p.

Stawikowski, R. 1983. SpätkommtIhr, dochIhrkommt. Ein Methusalemals Novität: Der Gestreifte Erd fresser. Aquarien Magazin, 17: 252-259.

Taylor, W. R. \& G. C. Van Dyke. 1985. Revised procedures for staining and clearing small fishes and other vertebrates for bone and cartilage study. Cybium, 9: 107-119.

Wimberger, P. H., R. E. Reis \& K. R. Thornton. 1998. Mitochondrial phylogenetics, biogeography, and evolution of parental care and mating systems in Gymnogeophagus (Perciformes: Cichlidae). Pp. 509-518. In: Malabarba, L. R., R. E. Reis., R. P. Vari., Z. M. S. Lucena \& C. A. S. Lucena (Eds.). Phylogeny and classification of Neotropical fishes. Porto Alegre, Edipucrs.

Winemiller, K. O., L. C. Kelso-Winemiller \& A. L. Brenkert. 1995. Ecomorphological diversification and convergence in fluvial cichlid fishes. Environmental Biology of Fishes, 44: 235-261.

Yafe, A., M. Loureiro, F. Scasso \& F. Quintans. 2002. Feeding of two Cichlidae species (Perciformes) in an hypertrophic urban lake. Iheringia, Série Zoologia, 92: 73-79. 